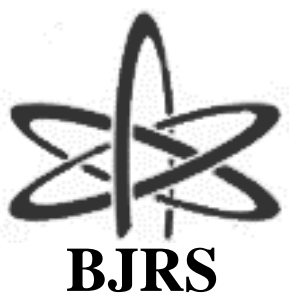

BRAZILIAN JOURNAL

$\mathrm{OF}$

RADIATION SCIENCES

07-02A (2019) 01-14

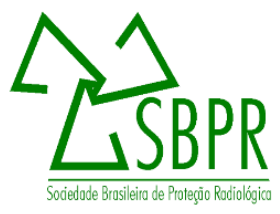

\title{
Study on elements concentrations on seabird feathers by instrumental neutron activation analysis
}

\author{
C. Y. S. Theophilo ${ }^{1}$; R. C. L. Figueira ${ }^{2}$; F. I. Colabuono ${ }^{2}$; R. C. Montone ${ }^{2}$; E. G. Moreira ${ }^{1}$ \\ ${ }^{1}$ Nuclear and Energy Research Institute/Research Reactor Center, Avenida Lineu Prestes, 2242 \\ 05508-000, São Paulo, São Paulo, Brazil. \\ ${ }^{2}$ Oceanographic Institute/ University of São Paulo/Marine Inorganic Chemistry Laboratory, Praça do Oceanográfico, \\ 191, 05508-120, São Paulo, São Paulo, Brazil. \\ Corresponding author: carolina.theophilo@gmail.com
}

\begin{abstract}
Seabirds are very sensitive to environmental changes and due to their large longevity, they are also sensitive to cumulative impacts. These birds usually occupy the higher trophic levels. White-chinned petrel (Procellaria aequinoctialis) and black-browed albatross (Thalassarche melanophris) are Procellariiformes, which is a seabird order, composed of 4 families. In the last years, researches are being done and actions are being taken to reduce the mortality of albatrosses and petrels caused by human activities. Due to the great ecological importance of these birds and the developed work with Procellariiformes, this study purpose was to quantify the $\mathrm{Br}, \mathrm{Cl}, \mathrm{Cu}, \mathrm{K}$, $\mathrm{Mg}, \mathrm{Mn}$, Na and $\mathrm{V}$ elements in white-chinned petrel and black-browed albatross feathers. Bird specimens were collected by the Albatross Project with permission of collection given by ICMBio (SISBIO 19560-1). The specimens were killed accidentally by pelagic longline fisheries operating off southern Brazil. Feathers were cleaned with acetone and then milled in a cryogenic mill. Instrumental Neutron Activation Analysis (INAA) was used for quantification of the element concentrations and measurements of induced activities were performed in a High Purity Germanium (HPGe) detector for gamma ray spectrometry. The obtained results on feathers showed that concentrations in these birds are not higher than others studies with the same species and, with exception of $\mathrm{Br}$, there are no significant differences between elements mean concentrations in the two seabirds.
\end{abstract}

Keywords: Elements, INAA, Thalassarche melanophris, Procellaria aequinoctialis, Feather. 


\section{INTRODUCTION}

Physical, chemical and biological variations are intrinsic characteristics of the ecosystems, so their conservation and management depend essentially on the correct interpretation of such modifications and their effects on the fauna and flora. Even though obtaining of physicochemical data is indispensable for the evaluation of the changes in a given environment, biological parameters can provide more insightful information about the true effect of environmental fluctuations on living organisms [1]. Ecological studies with biological indicators are prominent in environmental monitoring research. Moreover, considering the global scene of economic development, these studies are becoming increasingly necessary.

Nowadays seabirds are one of the most threatened vertebrate groups due to the impact on the ocean caused by human actions. They are sensitive to changes in the environment and this is one of the main reasons they are commonly used to monitor ocean pollution [2]. Seabirds occupy higher trophic levels, this also allows the integration of information on variations that occur at the base of the trophic chain. Besides, they are sensitive to cumulative impacts because of their large longevity [3].

Procellariiformes is a seabird order, composed of 4 families, and several countries with important breeding and feeding areas have shown interest in the conservation of these birds in the last decades and have invested in research and actions that reduce the mortality of albatrosses and petrels caused by human actions.

One of these initiatives was the creation of the Agreement on the Conservation of Albatrosses and Petrels (ACAP), which Brazil has been a signatory since 2001. ACAP is an international agreement that includes countries that are legally obliged to take long-term actions to ensure the conservation of various species of albatrosses and petrels [4]. Thus, Brazilian researchers, with government support, have developed a National Plan for the Conservation of Albatrosses and Petrels (Planacap), which aims to characterize threats to this group of birds and prioritize actions for these species conservation. Among the actions suggested for conservation are the continuous monitoring of populations, permanent research in the main reproductive colonies and the study of dispersion and migration of the species [5]. 
White-chinned petrel (Procellaria aequinoctialis) and black-browed albatross (Thalassarche melanophris) are two species that belong to Procellariiformes order. According to the red list of International Union for Conservation of Nature (IUCN), which is globally known as the most comprehensive way to assess the conservation status of animal and plant species [6], black-browed albatrossis classified like Near Threatened, because there are no estimates that their populations are declining. However, there is a certain degree of concern about this species, since a large number of individuals are killed in longline and trawl fisheries in the South Atlantic and in southern Africa. In South Africa, a minimum of 5000 individuals were estimated to be killed per annum [7; 8]. A few years ago, from 2002 to 2012, the black-browed albatross was listed as Endangered by the red list [8].

White-chinned petrel is one of the most abundant seabird species in the Southern Ocean. However, due to rapid population declines, it is classified as vulnerable in the IUCN red list. It is believed that the chicks predation and the degradation of breeding habitat contribute to it, furthermore, very high rates of incidental mortality by longline fishery have been recorded in recent decades [9; 10]. White-chinned petrel is one of the most common species killed by this type of fishery, during the winter, in the south-east Brazil [11]. Both species were in the 2003 National list of species threatened of extinction made by Ministry of Environment of Brazil [12], but in the recent list of 2014, only white-chinned petrel is present and classified like vulnerable [13].

Black-browed albatrosses are pelagic seabirds with a circumpolar distribution and are the most abundant albatross species in the southern hemisphere $[14 ; 15 ; 16]$. Their diet is composed mainly of fish, crustacean and cephalopods, but can also feed fishery discards and carrion [7; 16; 17]. White-chinned petrels are distributed in the sub-Antarctic region, but range widely at the sea [10; 18]. They are more active during the night and can dive approximately $15 \mathrm{~m}$, and their diet is very similar with to the one of black-browed albatross, being composed of fish, cephalopods and crustaceans too $[11,19 ; 20]$.

As seabirds are generally top predators with a long life and prolonged breeding cycles, they tend to accumulate pollutants, furthermore, due to the great importance of these birds and the developed work with Procellariiformes, the main aim of this study was to propose the quantification of the elements: $\mathrm{Br}, \mathrm{Cl}, \mathrm{Cu}, \mathrm{K}, \mathrm{Mg}, \mathrm{Mn}, \mathrm{Na}$ and $\mathrm{V}$ in White-chinned Petrel (Procellaria aequinoctialis) and Black-browed Albatross (Thalassarche melanophris) feathers. 


\section{MATERIALS AND METHODS}

\subsection{Sampling}

The seabird samples used in this study were obtained in partnership with the Albatross Project. The Albatross Project collected the samples with the permission of the Chico Mendes Institute for the Conservation of the Biodiversity (ICMBio) (SISBio 19560-1 license) and provided them for the study "Organochlorine contaminants in albatrosses and petrels during migration in South Atlantic Ocean" [21] and a part of these samples was assigned to this study. These specimens were killed accidentally by pelagic longline fisheries in southern Brazil, between latitudes of $27^{\circ} \mathrm{S}$ and $34^{\circ} \mathrm{S}$ and longitudes of $47^{\circ} \mathrm{W}$ to $52^{\circ} \mathrm{W}$ (Figure 1 ).

Figure 1: Seabirds sampling places.

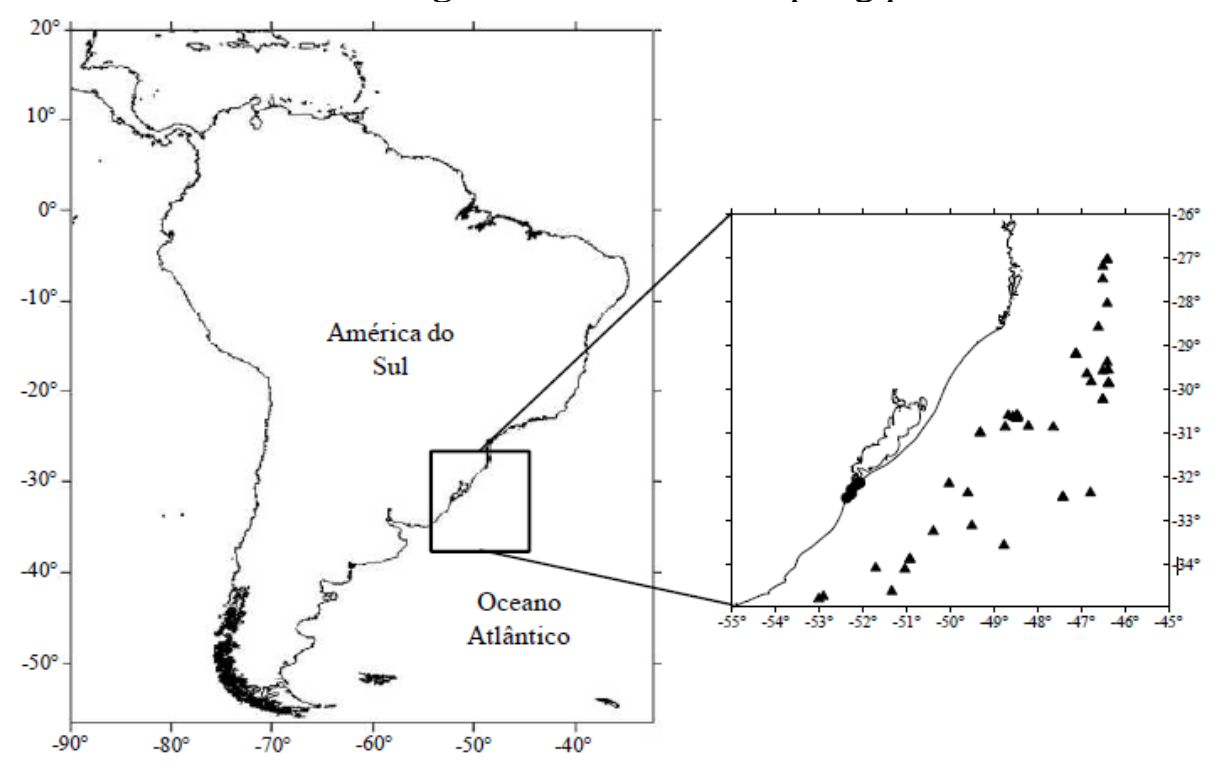

Source: COLABUONO, 2011 [21].

\subsection{Determination of elements by INAA}


In this study the elements $\mathrm{Br}, \mathrm{Cl}, \mathrm{Cu}, \mathrm{K}, \mathrm{Mg}, \mathrm{Mn}, \mathrm{Na}$ and $\mathrm{V}$ were quantified in white-chinned petrel and black-browed albatross feathers by Instrumental Neutron Activation Analyses (INAA). Before the analyses, feathers were cleaned with acetone and then milled in a cryogenic mill (6770 Freezer/Mill, Spex Sample Prep). For INAA, aliquots of $100 \mathrm{mg}$ of samples were irradiated for $30 \mathrm{~s}$ at a pneumatic system of the IEA-R1 research reactor along with standards of the elements of interest. To control the quantification technique use'd, aliquots of $100 \mathrm{mg}$ of certified reference material (CRM) were irradiated. The CRM used in this study was mussel tissue, which was made in Research Reactor Center/ IPEN. Measurements of gamma radiation were performed using a Camberra HPGe detector and the spectra were collected and processed by Camberra Genie 2000 program. Table 1 presents the nuclear data of the radionuclides quantified in this study. The concentrations of the elements were calculated using a spreadsheet (Microsoft Excel).

Table 1: Nuclear data of the radioisotopes used in this study [23].

\begin{tabular}{ccc}
\hline Radionuclides & Half-time & Gamma-ray energy (keV) \\
\hline${ }^{82} \mathrm{Br}$ & $17.68 \mathrm{~min}$ & 616.3 \\
${ }^{38} \mathrm{Cl}$ & $37.24 \mathrm{~min}$ & 1642.7 \\
${ }^{66} \mathrm{Cu}$ & $5.10 \mathrm{~min}$ & 1039.2 \\
${ }^{42} \mathrm{~K}$ & $12.36 \mathrm{~h}$ & 1524.4 \\
${ }^{27} \mathrm{Mg}$ & $9.46 \mathrm{~min}$ & 843.3 \\
${ }^{56} \mathrm{Mn}$ & $2.58 \mathrm{~h}$ & 846.8 \\
${ }^{24} \mathrm{Na}$ & $14.96 \mathrm{~h}$ & 1368.6 \\
${ }^{52} \mathrm{~V}$ & $3.75 \mathrm{~min}$ & 1434.1 \\
\hline
\end{tabular}

\section{RESULTS AND DISCUSSION}

\subsection{Quantified elements in seabird species}

Table 2 presents the certified [24] and obtained values to the elements of interest of this study in mussel tissue CRM, this material was used to control the quantification technique. Obtained values to $\mathrm{Br}, \mathrm{Cl}, \mathrm{Cu}, \mathrm{K}, \mathrm{Mg}, \mathrm{Mn}, \mathrm{Na}$ and $\mathrm{V}$ were similar to certified.

Table 2: Certified and obtained values, in $\mathrm{mg} \mathrm{kg}^{-1}$, of mussel tissue CRM used in this study. 


\begin{tabular}{ccc}
\hline Element & Certified value & Obtained value \\
\hline $\mathrm{Br}$ & $250 \pm 42$ & $224 \pm 73$ \\
$\mathrm{Cl}$ & $36200 \pm 4300$ & $39400 \pm 6400$ \\
$\mathrm{Cu}$ & $11.7 \pm 1.5$ & $13.4 \pm 0.73$ \\
$\mathrm{~K}$ & $8100 \pm 1100$ & $7408 \pm 66$ \\
$\mathrm{Mg}$ & $3600 \pm 43$ & $3445 \pm 21$ \\
$\mathrm{Mn}$ & $23.4 \pm 3.1$ & $21.2 \pm 0.73$ \\
$\mathrm{Na}$ & $22700 \pm 3600$ & $21955 \pm 1878$ \\
$\mathrm{~V}$ & $2.89 \pm 0.82$ & $2.52 \pm 0.10$ \\
\hline
\end{tabular}

In Table 3 are shown the results of the concentration of the elements obtained by INAA in the two seabird species: white-chinned petrel and black-browed albatross. The mean result, standard deviation, maximum and minimum values and the number of samples, $\mathrm{n}$, in which the elements were quantified are presented. Figure 2 presents the Box Plots of these quantified elements in the feathers of these two seabird species.

Table 3: Concentrations of quantified elements in white-chinned petrel and black-browed albatross.

\begin{tabular}{ccccccc}
\cline { 2 - 6 } & \multicolumn{2}{c}{ White-chinned petrel } & \multicolumn{3}{c}{ Black-browed albatross } \\
\hline $\begin{array}{c}\text { Element } \\
\mathrm{mg} \mathrm{kg}^{-1}\end{array}$ & $\begin{array}{c}\overline{\boldsymbol{X}} \pm \boldsymbol{S D} \\
\mathrm{mg} \mathrm{kg}^{-1}\end{array}$ & $\begin{array}{c}\text { Min - Max } \\
\mathrm{mg} \mathrm{kg}^{-1}\end{array}$ & $\mathbf{n}$ & $\begin{array}{c}\overline{\boldsymbol{X}} \pm \boldsymbol{S D} \\
\mathrm{mg} \mathrm{kg}^{-1}\end{array}$ & $\begin{array}{c}\text { Min }- \text { Max } \\
\mathrm{mg} \mathrm{kg}^{-1}\end{array}$ & $\mathbf{n}$ \\
\hline $\mathrm{Br}$ & $0.34 \pm 0.16$ & $0.13-0.57$ & 10 & $2.0 \pm 1.3$ & $0.12-3.6$ & 10 \\
$\mathrm{Cl}$ & $14291 \pm 5203$ & $4552-21341$ & 10 & $14418 \pm 6866$ & $6730-26673$ & 10 \\
$\mathrm{Cu}$ & $1.7 \pm 1.2$ & $0.76-4.6$ & 9 & $1.4 \pm 0.91$ & $0.03-1.9$ & 4 \\
$\mathrm{~K}$ & $1016 \pm 552$ & $394-2389$ & 10 & $955 \pm 348$ & $504-1432$ & 10 \\
$\mathrm{Mg}$ & $1100 \pm 171$ & $815-1363$ & 10 & $1174 \pm 247$ & $852-1568$ & 10 \\
$\mathrm{Mn}$ & $0.88 \pm 0.79$ & $0.17-3,0$ & 10 & $0.66 \pm 0.25$ & $0.36-1.3$ & 10 \\
$\mathrm{Na}$ & $4335 \pm 1494$ & $2428-6694$ & 10 & $5807 \pm 1955$ & $3428-9212$ & 10 \\
$\mathrm{~V}$ & $0.12 \pm 0.09$ & $0.01-0.28$ & 8 & $0.19 \pm 0.14$ & $0.02-0.43$ & 6 \\
\hline
\end{tabular}

Figure 02: Box Plots of quantified elements in white-chinned petrels ( $P$. aequinoctialis) and blackbrowed albatrosses (T. melanophris). 


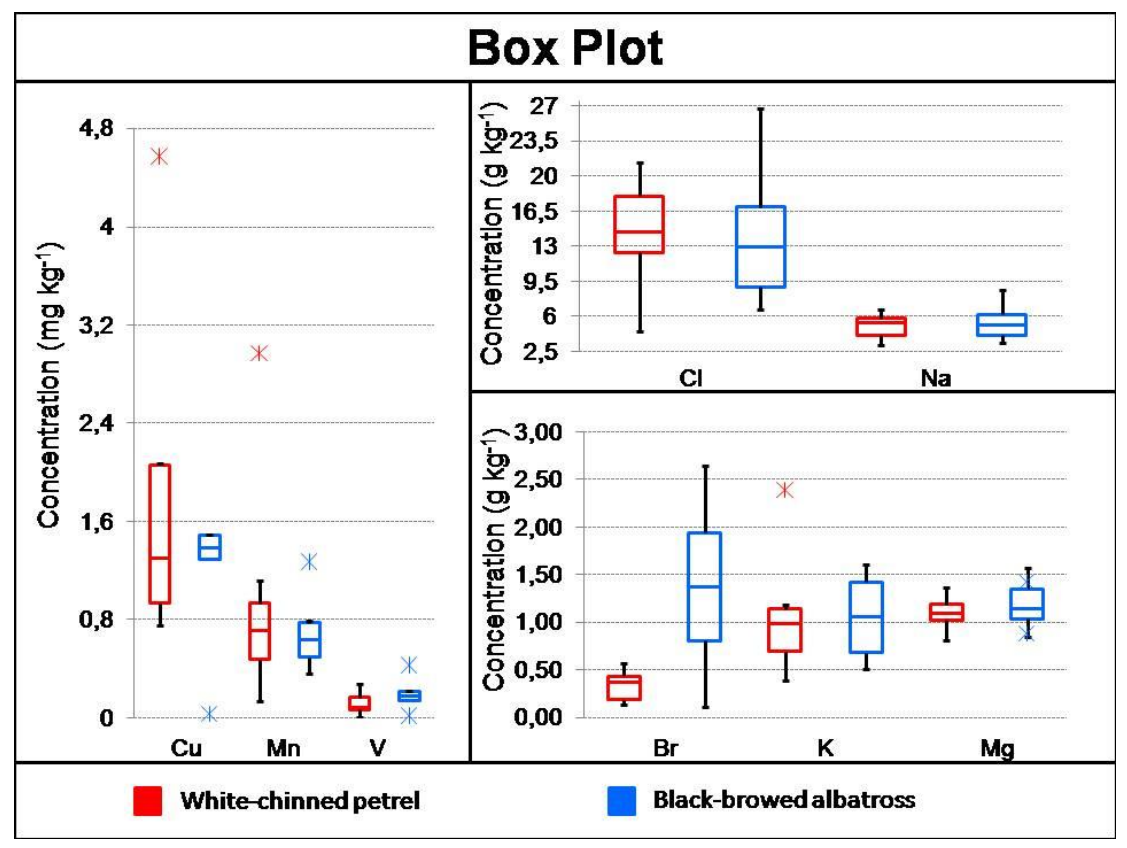

Some elements, such as $\mathrm{Cu}, \mathrm{K}, \mathrm{Na}, \mathrm{Fe}$, are found in the biological system of organisms because these elements are essential for metabolic activities. However, there are others elements that have no function in the organism, as for example $\mathrm{Cd}, \mathrm{Pb}$ and $\mathrm{Hg}[25 ; 26 ; 27]$. But even the elements that have metabolic function, if they are in quantities greater than necessary may end up accumulating and become harmful [28; 29].

In seabirds there is a gland, called salt gland that is responsible for eliminating excess salt in bird organisms, once they ingest salt water [30], but $\mathrm{Na}$ is the main electrolyte osmotically active of plasma and urine of the birds [31] and adequate concentrations of $\mathrm{Na}$ and $\mathrm{K}$ are required for the sodium-potassium pump operation, which is involved in the natural process of muscle contraction, including the heart muscle [32]. However, at high concentrations, $\mathrm{Na}^{+}$ions accumulate and may cause a higher water retention leading to an increase in extracellular and blood fluid, as a result there is an increase of heart work [31]. High concentrations of $\mathrm{K}$ in birds can cause muscle weakness, paralysis and heart problems [31].

There is no legislation on maximum concentrations of elements in wild animals to avoid damage, but the concentrations of this study can be compared with other studies already performed, as shown in Table 4. However, no studies were found that show the $\mathrm{Br}, \mathrm{Cl}, \mathrm{K}, \mathrm{Mg}$ and $\mathrm{Na}$ 
concentrations in white-chinned petrels and black-browed albatrosses, but it was found one study that quantified $\mathrm{Br}$ and $\mathrm{Na}$ by INAA in others species of bird.

Table 4: Comparison of the concentrations of the toxic elements quantified, in $\mathrm{mg} \mathrm{kg}^{-1}$, with literature.

\begin{tabular}{|c|c|c|c|c|c|c|}
\hline \multirow{2}{*}{ Species [Ref.] } & \multicolumn{5}{|c|}{ Element } & \multirow{2}{*}{ Technique } \\
\hline & $\mathrm{Br}$ & $\mathrm{Cu}$ & Mn & $\mathrm{Na}$ & V & \\
\hline P. aequinoctialis ${ }^{\mathrm{a}}$ & $0.34 \pm 0.16$ & $1.7 \pm 1.2$ & $0.88 \pm 0.79$ & $4.3 \pm 1.5$ & $0.12 \pm 0.09$ & INAA \\
\hline T. melanophris ${ }^{\mathrm{a}}$ & $2.0 \pm 1.3$ & $1.4 \pm 0.9$ & $0,66 \pm 0,25$ & $5.8 \pm 1.9$ & $0.19 \pm 0.14$ & INAA \\
\hline T. melanophris[33] & - & $4.8 \pm 1.7$ & - & - & - & AAS \\
\hline T. melanophris[34] & - & $8.6 \pm 12.0$ & - & - & - & ICP-MS \\
\hline P. aequinoctialis[10] & - & $6.0 \pm 2.6$ & $2.7 \pm 6.7$ & - & $0.3 \pm 0.8$ & AAS \\
\hline P. aequinoctialis[34] & - & $13.1 \pm 17.8$ & $1.3 \pm 1.0$ & - & $0.2 \pm 0.1$ & ICP-MS \\
\hline Ardeaalba[35] & $7.9 \pm 6.5$ & - & - & $700 \pm 4.2$ & - & INAA \\
\hline Coragypsatratus[35] & $6.2 \pm 6.1$ & - & - & $610 \pm 4.8$ & - & INAA \\
\hline Pachyptiladesolata[36] & - & $6.1 \pm 2.1$ & $1.1 \pm 0.7$ & & - & $\begin{array}{c}\text { ICP-OES/ } \\
\text { ICP-MS }\end{array}$ \\
\hline
\end{tabular}

${ }^{\text {a }}$ Present study.

Comparing this study with the others present in Table 4, it is possible to notice that the quantified concentrations of $\mathrm{Cu}$ and $\mathrm{Mn}$ are lower than those found in other studies for both seabird species. However, it is also possible to note that $\mathrm{V}$ concentrations found for both, white-chinned petrel and black-browed albatross, are similar between this study and the study made by Anderson (2010) [34].

After the descriptive statistics, a $t$-Student test was performed to compare the mean concentrations of the elements in the feathers of the two species of seabirds. The $t$-Student test is performed to investigate whether or not there are differences as means of two groups, therefore, in this study, it was used to determine if the mean concentrations of the elements quantified in white-chinned petrel 
are equal to or different from the mean concentrations found in black-browed albatross. Table 5 presents the $t$ value, $t$ critical value and $p$ value for each of the elements quantified in this study.

Table 5: $T$-Student test for comparison of elements quantified mean sod white-chinned petrels and black-browed albatrosses.

\begin{tabular}{cccc} 
& t-value & $\begin{array}{c}\boldsymbol{t} \text {-critical } \\
\text { value }\end{array}$ & $\boldsymbol{p}$-value \\
\hline $\mathrm{Br}$ & -3.9 & \pm 2.10 & 0.001 \\
$\mathrm{Cl}$ & -0.05 & \pm 2.10 & 0.96 \\
$\mathrm{Cu}$ & 0.41 & \pm 2.20 & 0.69 \\
$\mathrm{~K}$ & 0.29 & \pm 2.10 & 0.77 \\
$\mathrm{Mg}$ & -0.78 & \pm 2.10 & 0.44 \\
$\mathrm{Mn}$ & 0.86 & \pm 2.10 & 0.40 \\
$\mathrm{Na}$ & -1.9 & \pm 2.10 & 0.07 \\
$\mathrm{~V}$ & -1.2 & \pm 2.17 & 0.25 \\
\hline
\end{tabular}

With the results of $t$-Student test is possible observe that for most of the quantified elements $(\mathrm{Cl}$, $\mathrm{Cu}, \mathrm{K}, \mathrm{Mg}, \mathrm{Mn}, \mathrm{Na}, \mathrm{V})$ there were no differences between the average concentrations found in white-chinned petrels and black-browed albatrosses. The only one element that shows significant difference $(\mathrm{p}<0.05)$ between the species was $\mathrm{Br}$. Bromine is a naturally occurring element, it can occur in different forms in seawaters and earth's crust, it has a brownish-red color with a bleachlike odor, bromine can cause skin, mucous membranes, and tissues irritation [37]. Br is present in some organic compounds, like 1,2-dibromo-4-(1,2-dibromoethyl) cyclohexane, hexabromocyclododecane, tetrabromobisphenol A, these compounds are brominated flame retardant which have been used in a lot of consumers products, like plastics and foam [38; 39]. The use of these compounds is increasing and some studies have shown that they are able of causing damage to wildlife, in birds they can cause, for example, reproductive changes and affects the thyroid and sex steroid axes [38; 39].

$\mathrm{Cl}, \mathrm{Cu}, \mathrm{K}, \mathrm{Mg}, \mathrm{Mn}, \mathrm{Na}, \mathrm{V}$ are essentials elements for metabolic activities, similar concentrations for most elements may be due to dietary food, which is very similar in both seabirds, the two species feed mainly of fish, crustaceans, cephalopods, besides fishery discards $[7 ; 11 ; 16,17 ; 19 ; 20]$.

\section{CONCLUSION}


The objectives proposed by the study were fulfilled and the elements $(\mathrm{Cl}, \mathrm{Cu}, \mathrm{K}, \mathrm{Mg}, \mathrm{Mn}, \mathrm{Na}$ and V) were quantified in white-chinned petrel and black-browed albatross feathers. This study has a great importance, because major efforts are made to protect Procellariiformes, therefore the study can contribute to a database formation, since there is not much information about the concentrations of some elements in the literature. Suggestions for future studies would be the quantification of these elements in other tissues and other elements in feathers and tissues, for a greater understanding, monitoring and conservation of the species.

\section{ACKNOWLEDGMENT}

The authors would like to thank the Albatross Project for providing the feather samples and CAPES for the Ph. D awarded scholarship (Carolina Y. S. Theophilo).

\section{REFERENCES}

1. RAMOS, J. A. As aves marinhas como indicadores ecológicos. Universidade de Coimbra, Faculdade de Ciência e Tecnologia, 17p, 2010.

2. CAlle, P.; Alvarado, O.; MONSERRATE; L., CEVAllos, J. M.; CAlle, N.; AlAVA, J. J. Mercury accumulation in sediments and seabird feathers from the Antarctic Peninsula. Mar Pollut Bull, v. 91,p.410-417, 2015.

3. FURNESS, R. W.; CAMPHUYSEN, C. J.; Seabirds as monitors of the marine environment. J Mar Sci, v. 54, p. 726-737, 1997.

4. IBAMA - Instituto Brasileiro Do Meio Ambiente E Dos Recursos Naturais Renováveis. Plano de Ação Nacional para a Conservação de Albatrozes e Petréis (Planacap), Série Espécies Ameaçadas 2, 124 p, 2006.

5. ACAP - Agreement on the Conservation of Albatrosses and Petrels. The Agreement on the Conservation of Albatrosses and Petrels. Available at: <http://www.acap.aq >.Last accessed: 15 Aug. 2017.

6. IUCN - International Union for Conservation of Nature. Overview of the IUCN Red List. Available at: <http://www.iucnredlist.org/about/overview\#>. Last accessed: 28 Jul. 2017. 
7. BIRDLIFE. Species factsheet: Thalassarche melanophris. Available at: $<$ http://datazone.birdlife.org/species/factsheet/black-browed-albatross-thalassarchemelanophris>Last accessed: 26 Jul. 2017.

8. IUCN - International Union for Conservation of Nature. Thalassarche melanophris (Blackbrowed

Albatross).

Available

at: <http://dx.doi.org/10.2305/IUCN.UK.20163.RLTS.T22698375A93680491.en>. Last accessed: 01Aug. 2017.

9. IUCN - International Union for Conservation of Nature. "Procellaria aequinoctialis (Whitechinned Petrel). Available at:<http://dx.doi.org/10.2305/IUCN.UK.20171.RLTS.T22698140A112245853>.en. Last accessed: 01Aug. 2017.

10. CIPRO, C. V. Z.;CHEREL, Y.; CAURANT, F.;MIRAMAND, P.;MÉNDEZ-FERNANDEZ, P.;BUSTAMANTE, P. Trace elements in tissues of white-chinned petrels (Procellaria aequinoctialis) from Kerguelen waters, Southern Indian Ocean. Polar Biol, 37, p.763-771, 2014.

11. BIRDLIFE. Species factsheet: Thalassarche melanophris. Available at: $<$ http://datazone.birdlife.org/species/factsheet/black-browed-albatross-thalassarchemelanophris/text>. Last accessed: 26 Jul. 2017.

12. MMA - Ministério do Meio Ambiente. National list of Brazilian fauna species threatened of extinction $\quad-\quad 2003 . \quad$ Available <http://www.mma.gov.br/estruturas/179/_arquivos/179_05122008034002.pdf (2003)>. Last accessed: 03 Aug. 2017

13. MMA - Ministério do Meio Ambiente. "National list of Brazilian fauna species threatened of extinction - 2014". Available at: $<$ http://pesquisa.in.gov.br/imprensa/jsp/visualiza/index.jsp?data=18/12/2014\&jornal=1\&pagina $=122 \&$ totalArquivos=144>. Last accessed: 03 Aug. 2017.

14. BURG, T. M.; CATRY, P.; RYAN, P. G.; PHILlIPS, R. A. Genetic population structure of black-browed and Campbell albatrosses, and implications for assigning provenance of bird killed in fishiries. Aqua Conserv Mar Freshw Ecosyst, p. 1-8, 2017.

15. CAMPIONI, L.; GRANADEIRO, J. P.;CATRY, P. Albatrosses prospect before choosing a home: intrinsic and extrinsic sources of variability in visit rates. Animal behav, v. 128, p. 8593, 2017. 
16. ACAP - Agreement on the Conservation of Albatrosses and Petrels. Species assessment: Black-browed albatross Thalassarche melanophris. Available at: 〈http://www.acap.aq >. Last accessed: 08 Aug. 2017.

17. COPELlO, S.; BLANCO, G. S.; PON, J. P. S.; QUINTANA, F.; FAVERO, M. Exporting the problem: Issues with fishing closures in seabird conservation. Mar Policy, v.74, p. 120-127, 2016.

18. FRAINER, G.; DAUDT, N. W.; CARLOS, C. J. Aberrantly plumaged White-chinned Petrels Procellariaa equinoctialis in the Brazilian waters, south-west Atlantic Ocean. Mar Biodivers Rec, v. 8, 4p., 2015.

19. CARVAlHO, P. C.; BUGONI, L.; MCGILl, R. A. R.; BIANCHINI, A. Metal and selenium concentrations in blood and feathers of petrels of the genus Procellaria. Environ Toxicol Chem, v. 32, p. 1641-1648, 2013.

20. ACAP - Agreement on the Conservation of Albatrosses and Petrels. Species assessment: White-chinned Petrel Procellaria aequinoctialis. Available at: < http://www.acap.aq >. Last accessed: 07 Aug. 2017.

21. COLABUONO, F. I.; TANIGUCHI, S.; MONTONE, R. C. Organochlorine contaminants in albatrosses and petrels during migration in South Atlantic Ocean. Chemosphere, v. 86, p.701$708,2012$.

22. COLABUONO, F. I. Poluentes orgânicos persistentes e ingestão de plásticos em albatrozes e petréis (Procellariiformes), PhD thesis, Oceanography Institute, São Paulo University, 221p., 2011.

23. IAEA - International Atomic Energy Agency. Practical Aspects of Operating a Neutron Activation Analysis Laboratory, TECDOC-564, IAEA, Vienna, 241 p., 1990.

24. MOREIRA, E. G.; VASCONCELLOS, M. B. A.; MAIHARA, V. A.; CATHARINO, M. G. M.; SAIKI, M. Interlaboratory Comparison for the characterization of a Brazilian mussel reference material. J Braz Chem Soc, DOI: 10.21577/0103-5053.20170205.

25. TAVARES, T. M.; CARVALHO, F. M. Avaliação de exposição de populações humanas à metais pesados no ambiente: exemplos do Recôncavo Baiano. Quím Nova, v. 15, p. 147-154, 1992. 
26. AL-YOUSUF, M. H.; EL-SHAHAWI, M. S.; AL-GHAIS, S. M. Trace metals in liver, skin and muscle of Lethrinuslentjan fish species in relation to body length and sex. Sci Total Environ, v. 256, p. 87-94, 2000.

27. NOROUZI, M.; MANSOURI, B.; HAMIDIAN, A. H.; ZAREI, I.; MANSOURI, A. Metal concentrations in tissues of two fish species from Qeshm Island, Iran. Bull Environ Contam Toxicol, v. 89, p. 1004-1008, 2012.

28. ABDALLAH, M. A. M. Trace elements levels in some commercially valuable fish species from coastal waters of Mediterranean Sea, Egypt. J Mar Syst, v. 73, p. 114-122, 2000.

29. AGUIAR, M. R. M. P.; NOVAES, A. C.; GUARINO, A. W. S. Remoção de metais pesados de efluentes industriais por aluminossilicatos. Química Nova, v.25,p. 1145-1154, 2002.

30. SCHREIBER, E. A.; BURGER, J. Biology of Marine Bird, Boca Raton: CRC Press, 2001.

31. THRAlL, M. A.; WEISER, G.; ALLISON, R. W.; CAMPBELL, T. W. Veterinary Hematological and Clinical Chemistry, Ames: John Wiley \& Sons, 2012.

32. VOET, D.; VOET, J. Bioquímica, Porto Alegre: Artmed, 2006.

33. PON, J. P. S.; BELTRAME, O.; MARCOVECCHIO, J.; FAVERO, M.; GANDINI, P. Trace metals $(\mathrm{Cd}, \mathrm{Cr}, \mathrm{Cu}, \mathrm{Fe}, \mathrm{Ni}, \mathrm{Pb}$, and $\mathrm{Zn})$ in feathers of Black-browed Albatross Thalassarche melanophrys attending the Patagonian Shelf. Mar Environ Res, v. 72, p. 40-45, 2011.

34. ANDERSON, O. R. J.; PHILLIPS, R. A.;SHORE, R. F.;MCGILL, R. A. R.;MCDONALD, R. A.; BEARHOP, S. Element patterns in albatrosses and petrels: Influence of trophic position, foraging range, and prey type. Environ Pollut, v.158, p. 98-107, 2010.

35. FRANÇA, E. J.; FERNANDES E. A. N.; FONSECA, F. Y.; ANTUNES, A. Z.; BALDINI JUNIOR, C. BACCHI, M. A.; RODRIGUES, V. S.; CAVALCA, I. P. O. k0-INAA for determining chemical elements in bird feathers. Nucl Instr Meth Phys Res, v. 622, p. 473-478, 2010.

36. FROMANT, A.; CARRAVIERI, A.; BUSTAMANTE, P.; LABADIA, P.; BUDZINSKI, L. P.; CHURLAUD, C.; CHASTEL, O.; CHEREL, Y. Wide range of metallic and organic contaminants in various tissues of the Antarctic prion, a plankton ophagous seabird from the Southern Ocean. Sci Total Environ, v. 544, p. 754-764, 2016.

37. CDC - Centers for Disease Control and Prevention. Facts about bromine. Available at: <https://emergency.cdc.gov/agent/bromine/basics/facts.asp>. Last accessed: 06 de Aug. 2017. 
38. MARTEINSON, S. C.; LETCHER, R. J.; GRAHAM, L.; KIMMINS, S.; TOMY, G.; PALACE, V. P.; RITCHIE, I. J.; GAUTHIER, L. T.; BIRD, D. M.; FERNIE, K. J.; The Flame Retardant 及-1,2-Dibromo-4-(1,2-dibromoethyl)cyclohexane: Fate, Fertility, and Reproductive Success in American Kestrels (Falco sparverius). Environ. Sci. Technol., v. 46, p. 8440-8447. DOI: $10.1021 / \mathrm{es} 301032 \mathrm{a}$.

39. GAUTHIER, L. T.; POTTER, D.; HEBERT, C. E.; LETCHER. Temporal Trends and Spatial Distribution of Non-polybrominated Diphenyl Ether Flame Retardants in the Eggs of Colonial Populations of Great Lakes Herring Gulls. Environ. Sci. Technol., v. 43, p. 312-317. DOI: $10.1021 / \mathrm{es} 801687 \mathrm{~d}$ 